\title{
THE COMMUNICATIVE FUNCTIONS OF ULAON POGU NI ALAMAN IN EXHUMATION (MANGONGKAL HOLI) A FUNERAL CEREMONY IN TOBA BATAK
}

\author{
OSTI ELISABETH SIMANJUNTAK ${ }^{1}$, LIDIMAN SAHAT SINAGA2, SYAMSUL BAHRI ${ }^{3}$ \\ ${ }^{123}$ UNIVERSITAS NEGERI MEDAN
}

\begin{abstract}
This research focused on communicative functions used in Ulaon Pogu ni Alaman in Exhumation (Mangongkal Holi) at funeral ceremony in Toba Batak. This research was conducted by applying descriptive qualitative method. The data were collected from the transcript utterances of Ulaon Pogu ni Alaman at funeral ceremony in Toba Batak. The findings of the study show that there are 100 utterances which consist of six communicative functions which is referential, emotive, poetic, conative, phatic, and metalinguistic. The most dominant type of communicative functions used in Ulaon Pogu ni Alaman in Exhumation (Mangongkal Holi) at funeral ceremony in Toba Batak is referential function. It means that the communication used in Ulaon Pogu ni Alaman intended to establish the description and contextual information that happened on that day.
\end{abstract}

Keywords: communicative functions; Batak Toba; funeral ceremony; Ulaon Pogu ni Alaman.

\section{INTRODUCTION}

Communication is the key of a social interaction. People communicate to one another for their concern with information by using a medium of communication called language. Language is very important in life and language will not be free from human. Wehmeier (in Firnawaty, 2007: 1) explains that language is all the words that person uses in a particular language and the people use when the one talking about a particular subject. In conducting communication, people can express their feelings and emotions. People hope in order to interpret other people's language and expect other people to interpret their own in this way all time.

Every language that is uttered by people has different function and meaning. It depends on the context and situation. Jakobson (in Hebert, 2011: 3) highlights six communicative functions of language, there are: the referential function is oriented toward the context; the emotive (expressive) function is oriented toward the listener; the conative (action-inducing, such as a command) function is oriented toward the speaker; the metalingual (language speaking) function is oriented toward the code; and the poetic function is oriented toward the message. 
This study refers to the use of communicative function of language in the exhumation (Mangongkal Holi) in Toba Batak. The reason why the writer studies the communicative functions of language because of some people knows how to speak, but people do not know what the function of language itself.

\subsection{Communicative Functions of Language}

The linguist Jakobson has extended Bühler's model by adding further functions. Jakobson proposed three additional functions, making six fundamental factors, each assuming an orientation within the verbal message. As Jakobson (in Hebert, 2011: 3) has shown that in any given act of verbal communications (speech event), there are six fundamental factors which must be present for the act to be operable:

a. The Referential Function

The referential function is oriented toward the context. It is the one most commonly addressed because it concerns descriptions or contextual information. The people utter the information that happens factually to show the things or facts. The referential function is the most obvious function of language.

b. The Emotive Function

The emotive function is oriented toward the addresser. This function comes out when the people want to express their emotions although they do not speak any information. In this function, the people communicate themselves more than they communicate to other people who hear them.

c. The Conative Function

The conative function is oriented toward the addressee. This function finds it in imperative sentences; it helps the speaker make other people do something by the command. It may include orders and prayers.

d. The Phatic Function

The phatic function sets for a contact, which establishes, prolongs, and discontinues the communication. The use of this function is to know whether the channel works or whether the contact is still there. The purpose in this function firstly is to maintain the contact with the people who are talking to the speaker.

e. The Metalinguistic Function

The metalinguistic function is concerned with utterances that deal with language itself (of a linguistic nature), or what is sometimes called "code." The code used whenever the addresser and the addressee need to check whether they use the same code and when the language is used to speak about language in.

\section{f. The Poetic Function}


The poetic function deals with that language whose primary focus is the beauty of the language itself. The poetic function puts the focus on the message for its own sake. The poetic function involves the ability to manipulate language in a creative way. The poetic function appears in a speech event such as in political slogans, advertising, commemorative speeches.

\subsection{Toba Batak}

Toba Batak is the most numerous of Batak people of North Sumatera, Indonesia. Toba Batak often considered the classical 'Batak' most likely to willing self-identify as Batak. The Toba Batak people speak in the Toba Batak language and are centered on Lake Toba and Samosir Island within the lake (Sibarani, 1999: 15-16).

\subsection{Exhumation (Mangongkal Holi)}

Toba Batak tribe since the ancient time until today has retained the traditional and religious values inherited from their ancestors, although sometimes it is contrary to religious teachings. The cultural phenomenon Mangongkal Holi event is one of Toba Batak traditions that still survives and is preserved today in the origin area (bona pasogit) and in the overseas area (parserakan). This tradition persists because of the strong roots of traditional culture, cosmology, and religion of Toba Batak that influence their cognition.

\section{METHODOLOGY}

This research used descriptive qualitative method. This method applied because it is intended to analyze and describe the utterances those are used by each speaker. The research was defined to find out the communicative function of language using by Roman Jakobson on Communicative Function of Ulaon Pogu ni Alaman in Exhumation (Mangongkal Holi).

According to Holloway (2010: 3) qualitative research is a form of social inquiry that focus on the way of people interpret and make a sense of their experiences in the world. The aim of this method is to understand the social reality of individuals, groups, and cultures.

This study would analyze the data and the results are obtained from this study is a form of verbal data in words or phrases containing on the concept the language speaking of Ulaon Pogu ni Alaman's event. Then the data would be classified into the six models of communications by Jakobson's theory. The data would be taken from the 3 documentary videos of Ulaon Pogu ni Alaman in exhumation or Mangongkal Holi event in Toba Batak from Youtube. There are 100 utterances would be put on this research. Other source was the Toba Batak dictionary and the informants that helps the writer to be more understanding the language. 


\section{FINDINGS and DISCUSSIONS}

The Distribution of Each Type of Language Functions

Table 1. Types of Satire

\begin{tabular}{lll}
\hline No & Type of Language Function & frequency \\
\hline 1 & Referential Function & 31 \\
2 & Emotive Function & 5 \\
3 & Conative Function & 28 \\
4 & . Phatic Function & 15 \\
5 & Metalinguistic Function & 9 \\
6 & Poetic Function & 12 \\
\hline
\end{tabular}

\section{The Analysis of the Occurrence Types of Language Function}

\section{a. Referential Function}

The first type of language functions was referential with total amounts are 31 .

Referential function means provide or convey information. This function is oriented toward the context.

Example:

Nunga tarida sadarion uli lagumuna tu hami ai

Already seen today nice your hearts to us nunga saut tarpatupa songon na siningkapni rohanami already become organized like which according to our heart (Today, I have clearly seen your kindness towards us because of you have organized the traditional ceremony according to our wishes.)

The word sadarion shows the time when this event is held. It conducts the information of time. Then, the sentence nunga saut tarpatupa means that the information of action that had been done by people there. Mostly, the event of Ulaon Pogu ni Alaman is held in the noon until afternoon. However, it is organized during the day because the families and neighbours usually gather in the light of day. Mangongkal Holi ceremony is highly expected by all families. Therefore, everyone will rejoice when attending that ceremony. The family who organized the ceremony is very hopeful that all guests present will be happy. The guests will be given good service to protect the honor of their ancestors. If they are happy, it means the ceremony is being successful.

\section{b. Emotive Function}


The second type of language functions is emotive that only has 5. Emotive function means express the speaker's feelings. This function oriented toward the addresser.

Example:

$\mathrm{Bah} ! \rightarrow \mathrm{Ah} !$

The interjection above is used for expressing a feeling, as the example for showing that you are interested, surprised, pleased, and annoyed. In the context of situation, that word expressed in order to showing that they are interested when the dishes were coming and someone asked where he should place the dishes. The bah accent characterizes the Batak Toba people. The interjection can also be said to express surprising. Therefore, when the Batak people are surprised, they will say bah.

\section{c. Conative Function}

The third type of language functions is conative that has around 28. Conative function means attempt to get someone/ people to do something or it may include orders and prayers. It is oriented toward the addressee/ listener.

\section{Example:}

Tapuji ma Tuhanta $\rightarrow$ Let's praise which our God

(Let's praise our God.)

The words tapujima Tuhanta shows that the speaker wants the people there to do an action, like prayer. The event of Ulaon Pogu ni Alaman is also followed by a religious event. Usually, at the event, there is a priest who will lead the prayer. The word tapujima Tuhanta is always the beginning of the prayer to be said. In addition, these words can also be interpreted as singing. The priest will invite all guests to sing spiritual songs. It is conducted because Toba Batak people believe that God will always bless the ceremony.

\section{d. Poetic Function}

The third type of language functions is conative with 12 utterances. Poetic function focuses on the ability of speaker to manipulate language in a creative way.

Example:

Dia ma matana, dia ma haltona; Where which the eye where which big eye

Dia ma hatana, dia ma nidokmuna. Where which the words where which you say

(Which is the eye, that is the big eye

Which are the words, that is what you said)

The words above is formed by the ability in beauty of language. The speaker uses the words so that they look very interesting. It could be known by the use of alliteration (repeat consonant) and assonance (repeat vowel). The text above is one of the traditional poetry of Batak Toba. However, that text above is often pronounced during Batak Toba ceremonies 
because that text has no meaning. The purpose of the sentence is literally like the following sentence: "What does this mean?"

\section{e. Metalinguistic Function}

The sixth type of language functions is conative with total amounts are 9 sentences. Metalinguistic function means comment on the language itself which is used to discuss or describe. It focuses on the attention upon the code itself in order to clarify and negotiate it. Example:

Tu joloni ise ma peakkonnami sipanganon on? To in front of who which place dish it (In front of who do we place this dish?)

The words of tu joloni ise ma above shows that the speaker focused on the code by asking the question in order to negotiate something through the listener. In the Mangongkal Holi ceremony, how to put the object is a matter of great concern. For example, during the event of Ulaon Pogu ni Alaman, the dish will bring at lunch is not just put on there. The dish will be placed in front of hulahula as the respected people.

\section{f. Phatic Function}

The fifth type of language functions is phatic with a total number of 15 sentences. Phatic function serves to establish, prolong, and discontinue the communication. It focuses on the contact by getting the attention of people surrounding.

Example:

Songon nidok ni umpasa ma $\rightarrow$ As says that traditional poetry which (As the traditional poetry says.)

The sentence above means that the speaker wanted to prolong the communication. After saying that sentence, so it will be continued with traditional poetry. In the event of Ulaon Pogu ni Alaman, the parhata (master of ceremony) will say several traditional poetry related to the theme of the ceremonies. For example, the traditional poetry contain advice to the family who are left dead will be raised in the Mangongkal Holi ceremony. Therefore, the traditional poetry is often spoken by people.

\section{DISCUSSION}

This part presents the discussion of the research findings. There are two research questions. The discussion focuses on the finding of the two proposed research questions. The first discussion is about the language functions that are applied by people in the Ulaon Pogu ni Alaman. The research found 100 utterances using by people in the Ulaon Pogu ni Alaman. The second question focuses on the classification of communcative function of language in Ulaon 
Pogu ni Alaman. The researcher found six types of communicative function of langugage in Ulaon Pogu ni Alaman. There are 31 utterances in referential functions, 5 utterances in emotive function, 28 utterances in conative function, 15 utterances in phatic functions, 9 utterances in metalinguistic function, and 12 utterances in poetic function. The findings of this research is related with the theory of communicative functions by Jakobson (1985). The most frequency types of communicative function in Ulaon Pogu ni Alaman is referential function. It is indicated the communication was used in Ulaon Pogu ni Alaman has showed the description and contextual information that happened on that ceremony.

\section{CONCLUSIONS AND SUGGESTIONS}

After analyzing the using of language function in Ulaon Pogu ni Alaman event, the conclusions can be drawn as follows:

1. There are six types of communicative functions of language used in Ulaon Pogu ni Alaman event, which are referential, poetic, emotive, conative, phatic, and metaliguistic function.

2. The dominant type of communicative function of language in Ulaon Pogu ni Alaman event is referential function with the 31 occurences.

3. Referential function is the dominant type of language function used in Ulaon Pogu ni

Alaman event. It has an implication that Ulaon Pogu ni Alaman event used that function mostly in all the utterances because this event is the traditional ceremony. The communication which was doing in Ulaon Pogu ni Alaman event established the description and contextual information that happened on that day.

\section{REFERENCES}

Aliyah, I. 2015. Language Functions of Toyota Advertisement Headlines. A Thesis State Islamic Sunan Kalijaga University. Yogyakarta.

Almurashi, W. 2016. An Introduction to Haliday's Systemic Functional Linguistic. Taibah University. Kingdom of Saudi Arabia. Vol. 4 (2016) pp. 70-80.

Andersen. P. 2008. Linguistics Semiotics: Saussure and Bühler Revisited. Copenhagen Business School. Denmark. Vol. 2 (2008) pp. 1-29.

Arista, S. 2014. Language Functions Used by the Main Character in Sherlock Holmes II: A Game of Shadows Movie. A Thesis. State University of Medan. Medan.

Armstrong, E. 2010. Language, Meaning, Context, and Functional Communication. ECU Publication. Bol. 24 (2010) pp. 480-496.

Asdar, M. 2017. An Analysis of Language Function in BPEC (Benteng Panynya English Club) in Fort Rotterdam. A Thesis. Allaudin State Islamic University. Makassar. 
Chandler, D. 2005. Semiotics for Beginners. Routledge. United Kingdom.

Corry. 2017. The Meaning of Tugu Construction (Tambak Na Timbo) in Batak Toba Life from the Religion Side in Samosir District. Airlangga University. Surabaya. Vol. 22 (2017) pp. 75-82.

Darmojuwono, S. 2016. Language, Culture, and Social Cognition. University of Indonesia. Jakarta. Vol. 17 (2016) pp. 121-133.

Ehala, M. 2010. Ethno-linguistic Vitalityand Intergroup Processes. Walter de Gruyter. Vol. 29 (2010) pp. 203-221.

Fitryah, U. 2017. Language Function in Maybelline Advertisement. A Thesis. State Islamic Kalijaga University. Yogyakarta.

Garcia, A., Rising, B. 2006. Culture and Communication. College of Management Georgia. USA. Vol. 13 (2006) pp. 23-40.

Haratyan, F. 2011. Halliday's SFL and Social Meaning. Islamic Azad Univesity. Singapore. Vol. 17 (2011) pp. 260-264.

Hebert, L. 2011. The Functions of Language. Univeriste du Quebec. www.signosemio.com/jakobson/functions-of-language.asp

Itulua, F. 2013. Sociological Concept of Cultural and Identity. Research Gate. www.researchgate.net/publication/259692390-

Sociological_concepts_of_culture_and_identity

Lannigan, R. 1991. Roman Jakobson's Semiotic Theory of Communication. Southern Illinois University. USA

Margutti, V. 2013. Academic Writing. Belo Horizonte.

Mosse, E. 2007. Communication Practices As Functions, Rituals, and Symbols: Challenges for Computerization of Paper Based Information System.

University of Oslo. Norway. Vol. 18 (2004) pp. 1-17. Jakobson, R. 1985. Verbal Art, Verbal Sign, Verbal Time. University of Minnesota. USA

Ritchie, J., \& Lewis, J. 2013. Qualitative Research Practice A Guide for Social Science Students and Researchers. Washington DC. USA

Saragih, A. 2011. Discourse Analysis: A Study on Discourse Based on Systemic Functional Linguistic Theory. State University of Medan. Medan.

Silalahi, C., Sibarani, R. 2016. Trilogy of Adat-Laws in Mangongkal Holi: An Ethical Approach on Batak Toba Societies Communication. Utah State University. USA. Vol. 5 (2016) pp. 13-25. 
Simanjuntak, H. 2017. Politeness in Saur Matua Batak Toba Funeral Ceremony. Nomensen HKBP University. Indonesia. Vol. 3 (2017) pp. 1-12.

Todorović, T., Toporišič, T. 2017. Language of Dressing as Communication System and its Functions - Roman Jakobson's Linguistic Method. University of Ljubljana. Slovenia. Vol. 25 (2017) pp. 125-133.

Tribus, Angela. 2017. The Communication Function of Language: An Exploration of Roman Jakobson's Theory in TESOL. SIT Graduate Institute. Vol. 5 (2017) pp. $1-34$. 